\title{
Research on Capital Structure of Listed Companies in the Growth Enterprise Market (GSM)
}

\author{
Yurong Gao
}

\author{
Shandong Women's University, Jinan, Shandong province, 250010, China \\ *Corresponding author. Email: gaoyurong1975@163.com
}

\begin{abstract}
Growth Enterprise Market (GEM) enriches the structure of China's capital market. As an important supplement to the main board market, it starts a new journey for the securities market. The discussion of the capital structure of China's GEM listed companies is of great significance to improve the development dilemma of Growth Enterprise Market companies. This paper took 794 GEM listed companies as samples to explore their current situation of capital structure. By analyzing their financial ratio of related financial indicators, this paper reveals their problems of low asset-liability ratio and liability structure in capital structure and analyzes the reasons behind, then gives some counter measurements based on China's conditions, such as optimizing the enterprise's financing structure, adjusting the debt structure and improving the ability of internal financing of the enterprise, in the hope that the research of this paper can provide references to the optimization of capital structure of GEM listed companies.
\end{abstract}

Keywords: Growth Enterprise Market, Capital Structure, Perfection Measures.

\section{INTRODUCTION}

The problem of the enterprise's capital structure has always been a hot topic that attracts people's attention for its effect on the future profitability, debt paying ability, refinancing ability and financial health of enterprises. According to the data of Annual Empirical Analysis Report of 2019 of Listed Companies in Shenzhen Stock Exchange Multi-level Capital Market, in 2019, the total operating revenue of GEM listed companies was RMB 1.6 trillion, a year-on-year increase of $11.7 \%$, significantly higher than the $3.8 \%$ revenue growth rate of industrial enterprises above designated size. Net profit was RMB 51.92 billion, with a year-on-year increase of $29.1 \%$. Growth Enterprise Market showed strong growth momentum driven by innovation. Enterprises of new technology, new industry, new business form, and new model are accelerating gathering in Growth Enterprise Market. Among current Growth Enterprise Market listed companies, more than ninety percent become high-tech enterprises, more than eighty percent have the core ability of independent research and development, and over seventy percent are strategic emerging industries. The gathering characteristics of industries of the new generation of information technology, biological medicine, new energy, and new materials are prominent.
Since the establishment of GEM, the average Research and Development intensity (the proportion of Research and Development expenditure in operating revenue) has always maintained at $5 \%$ or so, which is not only much higher than the average Research and Development level of $2.2 \%$ of the whole society, but also evidently higher than the overall level of $3 \%$ of Shenzhen market. Driven by innovation, the feature of high growth is very obvious. The compound annual growth rate of total operating revenue was $22.9 \%$ in the last five years, and the year-on-year growth rate of net profit of more than $30 \%$ of companies was over $20 \%$. Thus, we can see that China's GEM listed companies are developing and expanding at an unprecedented speed. Growth Enterprise Market is not only a strong supplement to the main board market, but also an important pillar of China's capital market. Hence, through the study and analysis of the current situation of capital structure of GEM listed companies in this paper, some targeted suggestions are put forward for GEM listed companies, expecting to contributing to the choice of financing strategies of enterprises. When analyzing the capital structure of GEM listed companies, this paper chooses GEM listed companies which were listed before January 1, 2015 as research samples with the number of samples being 794, and takes their financial indicators from 2015 to 2019 as research data. In this way, it not only avoids 
the defects of the cross-section data, but also reduces the occasionally brought by data of one year.

\section{THE CAPITAL STRUCTURE ANALYSIS OF GEM LISTED COMPANIES}

\subsection{Overall Analysis of Capital Structure}

Table 1. Average Asset-liability Ratio of Listed Companies on the Main Board and Growth Enterprise Market from 2015 to 2018

\begin{tabular}{c|l|l|l|l|l}
\hline Year & 2015 & 2016 & 2017 & 2018 & 2019 \\
\hline $\begin{array}{c}\text { GEM Listed } \\
\text { Companies }\end{array}$ & $28.48 \%$ & $28.61 \%$ & $31.82 \%$ & $34.98 \%$ & $36.78 \%$ \\
\hline
\end{tabular}

Note: The data were collected from China Stock Market \& Accounting Research Database.

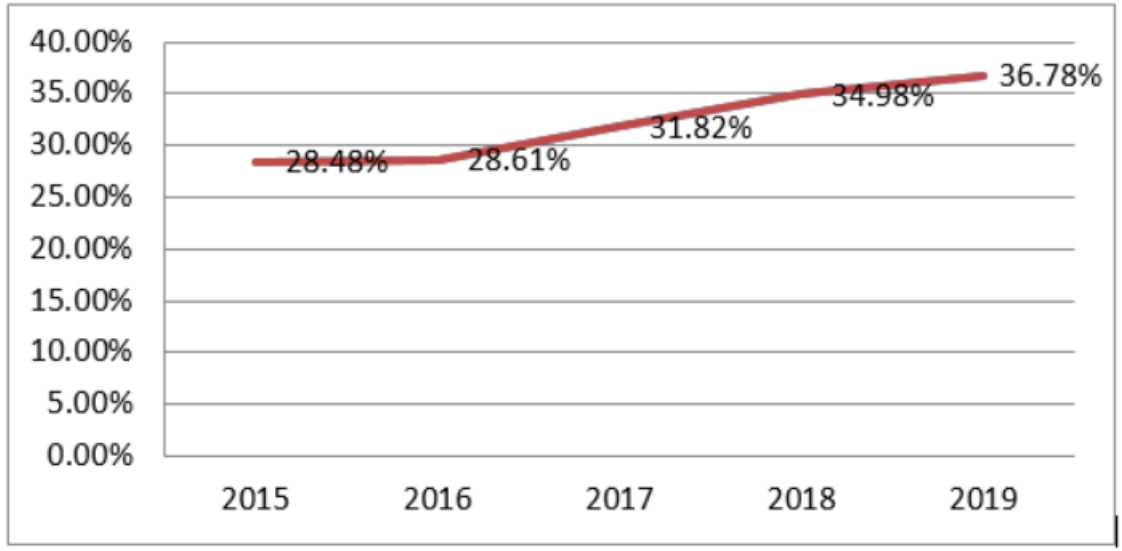

Figure 1 Changes of the average asset-liability ratio of GEM listed companies from 2015 to 2019

As we can see from Table 1, the asset-liability ratio of GEM listed companies from 2015 to 2019 was around 30\%. And from Figure 1, we can see that the GEM listed companies are in an upward trend generally.

Table 2. Descriptive statistical analysis of asset-liability ratio of GEM listed companies

\begin{tabular}{c|c|c|c|c|c|}
\hline Year & 2015 & 2016 & 2017 & 2018 & 2019 \\
\hline $\begin{array}{c}\text { Average } \\
\text { value }\end{array}$ & $28.48 \%$ & $28.61 \%$ & $31.82 \%$ & $34.98 \%$ & $36.78 \%$ \\
\hline $\begin{array}{c}\text { Maximum } \\
\text { value }\end{array}$ & $84.25 \%$ & $82.56 \%$ & $103.72 \%$ & $168.68 \%$ & $498.11 \%$ \\
\hline $\begin{array}{c}\text { Minimum } \\
\text { value }\end{array}$ & $1.69 \%$ & $0.08 \%$ & $0.04 \%$ & $0.01 \%$ & $0.007 \%$ \\
\hline $\begin{array}{c}\text { Intermedi } \\
\text { ate value }\end{array}$ & $25.06 \%$ & $26.29 \%$ & $28.90 \%$ & $32.71 \%$ & $33.48 \%$ \\
\hline $\begin{array}{c}\text { Standard } \\
\text { deviation }\end{array}$ & $16.10 \%$ & $16.39 \%$ & $17.75 \%$ & $20.64 \%$ & $28.35 \%$ \\
\hline Note: The
\end{tabular}

Note: The data were calculated from China Stock Market \& Accounting Research Database.

As we can see from Table 2, the gap between Assetliability ratios of GEM listed companies is large, with the maximum value of $498.11 \%$ and the minimum value of $0.007 \%$. The biggest gap appeared in 2019. Between 2015 and 2019, the gap has been increasing gradually, but it was still at a low level. The standard deviation 
was increasing year by year, which also indicates the increasing gap of the asset-liability ratio between GEM listed companies year by year. According to the statistic analysis of the asset-liability distribution over the years of GEM listed companies, this paper divides the assetliability level of enterprises into four ranges: $0-10 \%$, $10 \%-30 \%, 30 \%-50 \%$, and above $50 \%$. The statistic results can be seen in the following table:

Table 3. Distribution of assets and liabilities of GEM listed companies from 2015 to 2019

\begin{tabular}{c|c|c|c|c}
\hline Year & $0-10 \%$ & $10 \%-30 \%$ & $30 \%-50 \%$ & $50 \%$ 上 \\
\hline 2015 & $12.55 \%$ & $48.44 \%$ & $28.73 \%$ & $10.27 \%$ \\
\hline 2016 & $11.75 \%$ & $47.63 \%$ & $27.94 \%$ & $12.68 \%$ \\
\hline 2017 & $9.89 \%$ & $42.37 \%$ & $30.93 \%$ & $16.91 \%$ \\
\hline 2018 & $8.21 \%$ & $36.14 \%$ & $33.88 \%$ & $21.77 \%$ \\
\hline 2019 & $8.23 \%$ & $36.01 \%$ & $31.48 \%$ & $24.18 \%$ \\
\hline
\end{tabular}

Note: The data were calculated from China Stock Market \& Accounting Research Database.

From Table 3, the asset-liability distribution of Growth Enterprise Market listed companies from 2015 to 2019 , we can find that nearly $45 \%$ GEM listed companies have the asset-liability ratio of $10 \%-30 \%$, and only few companies have the asset-liability ratio above $50 \%$. But we can see from the data that companies with an asset-liability ratio of more than $50 \%$ is showing an upward trend.

\subsection{Analysis on Liability Structure}

Based on the enterprise's debt repaying speed or time, we divided liabilities into current debt and noncurrent debt, and the proportion relationship between them is related to the operational risk of the enterprise. Therefore, only by balancing the proportion of liability structure, can enterprises develop steadily.

Table 4. Composition of debt ratio of GEM listed companies from 2015 to 2019

\begin{tabular}{|c|c|c|c|c|c|}
\hline Year & 2015 & 2016 & 2017 & 2018 & 2019 \\
\hline Current debt ratio & $87.43 \%$ & $86.23 \%$ & $85.47 \%$ & $85.86 \%$ & $85.60 \%$ \\
\hline Non-current debt ratio & $12.57 \%$ & $13.76 \%$ & $14.53 \%$ & $14.14 \%$ & $14.40 \%$ \\
\hline
\end{tabular}

Note: The data were collected from China Stock Market \& Accounting Research Database.

Table 4 shows that the current debt ratio of GEM listed companies from 2015 to 2019 has been maintained at about $86 \%$ and the non-current debt ratio at about $13 \%$ Generally speaking, the current debt ratio of $30 \%-70 \%$ is reasonable, while the current debt ratio of such companies is obviously more than $70 \%$, indicating their weak debt repayment ability and facing of greater risks. 


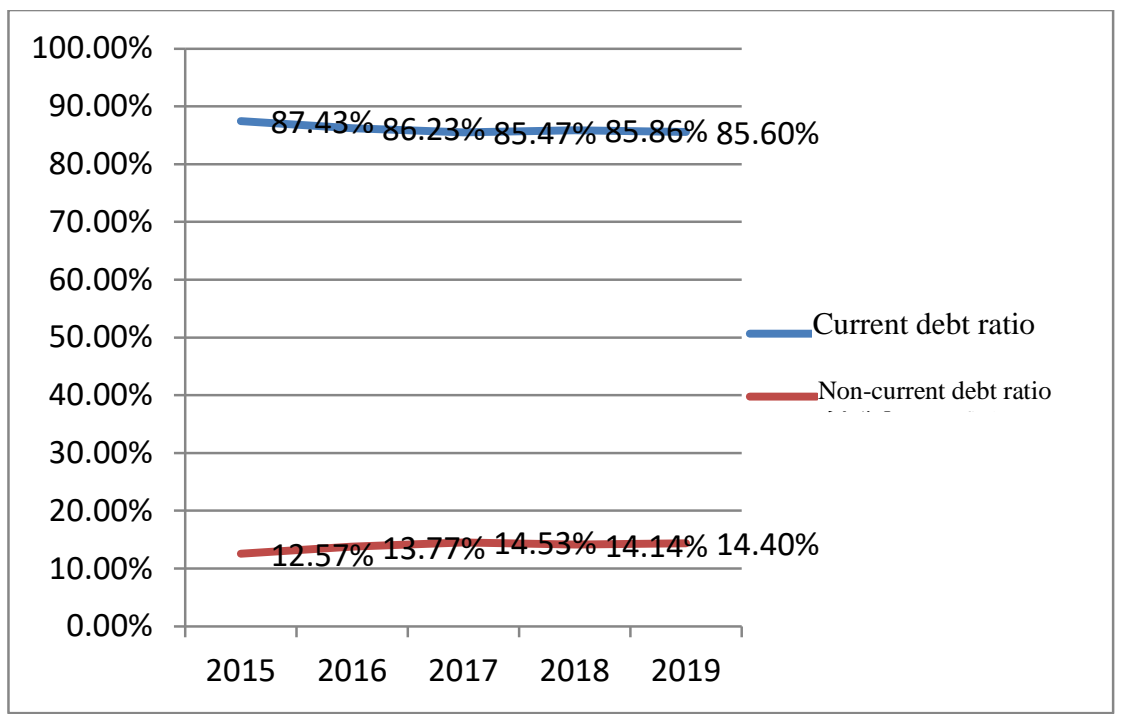

Figure 2 Changes in debt ratio of GEM listed companies from 2015 to 2019.

Figure 2 shows the slight decline of the current debt ratio of the enterprise, but which is still higher than the non-current debt ratio. With short-term debt being the main driving force for the development of the enterprise, the short-term debt repayment pressure of the enterprise will increase and the stability of enterprise development and the liquidity of funds will be affected.
The equity structure determines the enterprise's behavior and performance. The different equity size represents the different control degree over the enterprise. And the differences in financing methods and preferences will further affect the enterprise's capital structure.

\subsection{Analysis of Equity Structure}

Table 5. Equity structure of GEM listed companies from 2015 to 2019

\begin{tabular}{l|l|l}
\hline Year & Debt-equity ratio & Shareholders' equity ratio \\
\hline 2015 & $47.94 \%$ & $72.54 \%$ \\
\hline 2016 & $50.41 \%$ & $71.44 \%$ \\
\hline 2017 & $57.98 \%$ & $68.18 \%$ \\
\hline 2018 & $104.67 \%$ & $65.01 \%$ \\
\hline 2019 & $83.69 \%$ & $63.21 \%$ \\
\hline
\end{tabular}

Note: The data were collected from China Stock Market \& Accounting Research Database.

From the data in Table 5, we can find that there were some fluctuation in equity ratio of GEM listed companies from 2015 to 2019 , but the average value of equity ration in five years maintained at $68.94 \%$, while the usual equity ratio of $50 \%$ of enterprises is more reasonable, which indicates the large proportion of their own capital in the total assets of such companies and strong long-term debt repayment ability.

Table 5 also shows that the shareholders' equity ratio of the enterprise is about $70 \%$, which is relatively moderate, indicating the relatively stable control over the enterprise of the shareholders. 


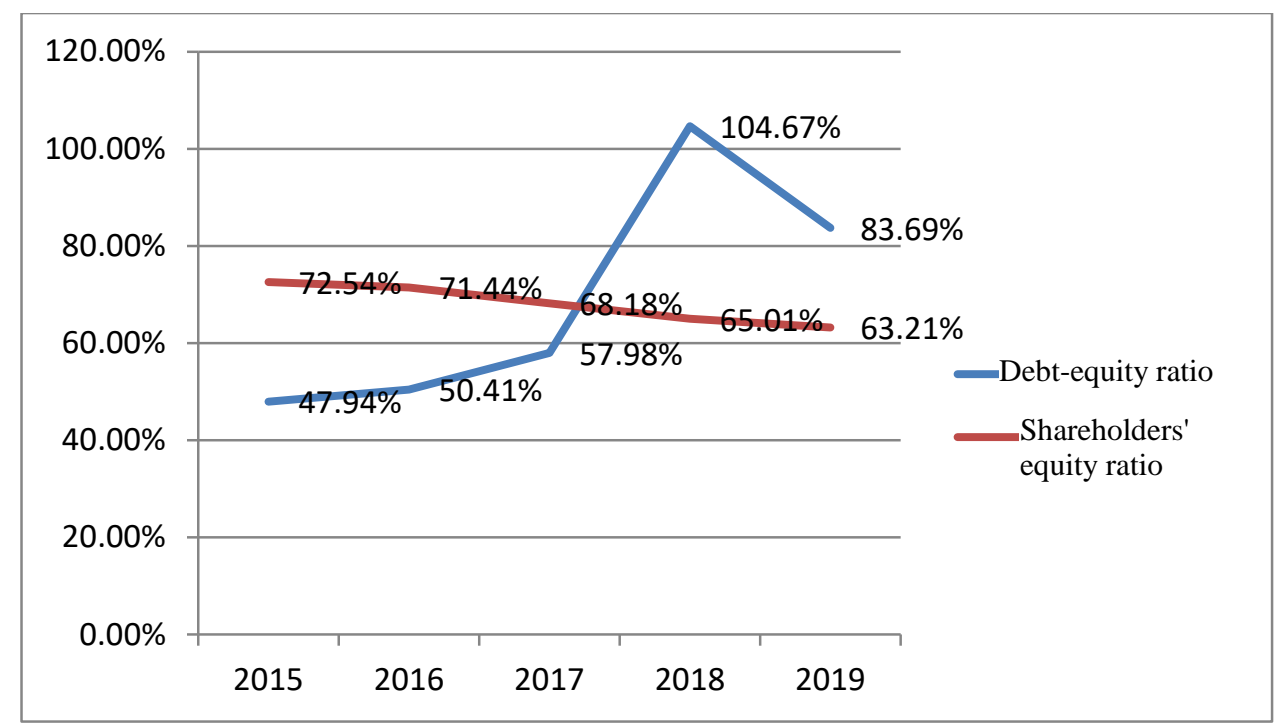

Figure 3 Changes in equity structure of GEM listed companies from 2015 to 2019.

Figure 3 can show the gradual decrease of the shareholders' equity ratio of the GEM listed companies, but the decrease is slight and the ratio is still relatively high, suggests that the GEM listed companies attach more importance to equity than creditor's rights. However, the enhancement of the asset-liability ratio indicates that enterprises start to consider creditor's rights financing.

Table 6. Statistics on equity concentration of GEM Listed companies from 2015 to 2019

\begin{tabular}{c|c|c|c|c|c}
\hline Year & 2015 & 2016 & 2017 & 2018 & 2019 \\
\hline $\begin{array}{l}\text { Shareholding ratio of the largest } \\
\text { shareholder }\end{array}$ & $32.11 \%$ & $33.09 \%$ & $28.58 \%$ & $27.13 \%$ & $27.13 \%$ \\
\hline $\begin{array}{l}\text { Shareholding ratio of the top ten } \\
\text { shareholders }\end{array}$ & $62.88 \%$ & $64.37 \%$ & $61.46 \%$ & $62.05 \%$ & $62.05 \%$ \\
\hline $\begin{array}{l}\text { Proportion of Tradable shares } \\
\text { Proportion of Non-tradable }\end{array}$ & $57.96 \%$ & $62.72 \%$ & $77.67 \%$ & $77.43 \%$ & $78.39 \%$ \\
\hline shares
\end{tabular}

Note: The data were collected from China Stock Market \& Accounting Research Database.

As we can see from Table 6, the proportion of tradable shares in the equity structure of GEM listed companies from 2015 to 2019 is relatively high, showing an upward trend and good equity liquidity. In terms of shareholding ratio of shareholders, the proportion of controlling shares of the largest shareholder and the top ten shareholders is high. In general, the equity of GEM listed companies belongs to a type of relative concentration.

\subsection{Analysis of Internal and External Financing Behavior}

Financing behavior is an indispensable link in enterprise development, aiming at meeting the needs of enterprise development and obtaining enterprise capital.
Based on whether the demander and the supplier of funds are the same subject, the financing methods of enterprises can be divided into internal financing and external financing, of which external financing can be further divided into equity financing and debt financing [13]. 
Table 7. Internal financing and external financing structure of GEM listed companies

\begin{tabular}{c|c|c|c}
\hline \multirow{2}{*}{ Year } & Proportion of & \multicolumn{2}{|c}{ Proportion of external financing } \\
\cline { 3 - 4 } & internal financing & Equity financing & Debt Financing \\
& & ratio & $17.04 \%$ \\
\hline 2015 & $43.38 \%$ & $59.37 \%$ & $18.94 \%$ \\
\hline 2016 & $21.67 \%$ & $51.21 \%$ & $27.33 \%$ \\
\hline 2017 & $21.45 \%$ & $41.55 \%$ & $24.51 \%$ \\
\hline 2018 & $33.94 \%$ & $80.59 \%$ & $24.65 \%$ \\
\hline 2019 & $-5.2 \%$ & & \\
\hline
\end{tabular}

Note: The data were calculated from China Stock Market \& Accounting Research Database.

Table 7 shows that external financing accounts for a high proportion, while internal financing accounts for a relatively low proportion in the financing methods of GEM listed companies from 2015 to 2019. In terms of internal methods, the proportion is relatively stable, with large changes from $43.38 \%$ to $-5.2 \%$ from 2015 to 2019 . The internal financing has not been fully utilized for it accounts for a low proportion. In terms of external methods, GEM listed companies prefer equity financing, with the proportion of equity financing keeping at about $50 \%$ from 2015 to 2019 . Overall, the financing structure of GEM listed companies is relatively stable, showing a tendency of preferring equity financing.

\section{EXISTING PROBLEMS AND REASONS IN CAPITAL STRUCTURE OF GEM LISTED COMPANIES}

\subsection{Existing Problems}

\subsubsection{Low Asset-liability Ratio and Insufficient Utilization of Financial Leverage}

It is generally thought that the reasonable range of asset-liability ratio for non-financial enterprises is $40 \%$ to $70 \%$. If the ration is lower than $30 \%$, which indicates that the enterprise has sufficient funding sources and less debts. But a moderate debt contributes to the enterprise's development and expansion of scale [1]. If an enterprise has a good future prospect and high growth potential, and the manager of the enterprise has good expectations for the enterprise future, then the enterprise should consider bonds financing first. What's more, the Growth Enterprise Market industry is strongly supported by our country. Thus, these enterprises should have advantages in tax policy and other aspects and get more benefits from tax saving. However, through the analysis of asset-liability situation of GEM listed companies from 2015 to 2019 , the asset-liability ratio of GEM listed companies is relatively low, obviously lower than the asset-liability ratio of the main board market, which indicates that the financial leverage of bonds has not been fully utilized.

\subsubsection{Unreasonable Liability Structure and High Current Debt Ratio}

Through the analysis of Table 4 above, we can find that the current debt ratio of GEM listed companies is slightly high, while the long-term debt ratio is slightly low. This reflects the dominating status of short-term debt in the liability structure of GEM listed companies. This composition is obviously unreasonable. Overreliance on short-term debt will increase the pressure of short-term debt repayment and short-term financial risks of enterprises. When facing a larger financial plight, problems like difficulty in capital turnover will arise. Overreliance on short-term debt will cause the short-termization of debt constraint and weaken the governance function. This reflects the deficiency in long-term debt management effect of GEM listed companies.

\subsubsection{Reliance on external financing causes high financing costs}

The pecking order theory of financing considers the sequentiality in financing cost, and believes that enterprise should consider "internal financing first, then external financing and debt financing first, then equity financing".[2] However, the order of choosing financing methods in most listed companies in China is different from the theory. They adopt the order of "external financing before internal financing and equity financing before debt financing." As we can see from Table 7 above, the choice of financing order of GEM listed companies is the same as that of most listed companies in China, which is obtaining the required funds from equity financing, and the proportion of internal financing is low. This will reduce the utilization rate of funds of the enterprise, weaken the financial leverage, and cause the enterprise to prefer equity financing. 


\subsection{Analysis of Reasons}

\subsubsection{Unbalanced Development of the Capital Market, and Resistance in Bonds Financing}

Although one of the main methods of broaden financing channels is to issue bonds, it is very difficult for GEM listed companies to issue bonds due to their small scale and low credit rating. In China's capital market, the development speed of the bond market is much lower than that of the stock market, because of the relatively strict issuance conditions of corporate bonds in China, the problems of single variety and small scale in bond market, and too much government intervention that also produces resistance to corporate bond financing. Thus, the imbalanced development of capital market and the imperfection of bond market in our country limit the financing methods of GEM listed companies [3]. In addition, by the above analysis, the preference for equity financing of GEM listed companies is also one of the reasons for their low assetliability ratio.

\subsubsection{The Difficulty of Obtaining Long-Term Loans for the Low Asset Credit Rating of the Enterprise}

The first reason is that most GEM listed companies are small and medium-sized enterprises with small scale, most of which belong to light asset industry, lack of tangible assets approved by the bank available for loan collateral; and due to the underdeveloped medium and long-term credit market and incomplete financial credit system of our country, there is some resistance from the bank currently on asset credit evaluation of such enterprises and the procedures and methods of credit loan. Thus, it is hard for these enterprises to obtain long-term loans from the bank. The second reason is that the cost of short-term debt is lower, and compared with long-term debt, its financial risk is easier to manage [4].

\subsubsection{The Relatively Low Profitability of the Enterprise and the Insufficient Internal Fund Accumulation}

Internal financing requires sufficient internal fund accumulation of the enterprise. However, the selfaccumulated cash flow of most GEM listed companies cannot meet the development needs of the enterprise for their high input cost, low income, and weak competitiveness in the market. The transformation and upgrading of China's enterprises is accelerating, and the costs of production and labor are rising, the profit space was compressed by the rising costs, and as the GEM listed companies continue to grow stronger, the expansion rate of assets is much faster than the growth of the internal retained earnings, making GEM listed companies begin to rely on external financial market.

\section{SUGGESTIONS ON THE OPTIMIZATION OF CAPITAL STRUCTURE OF GEM LISTED COMPANIES}

\subsection{Improve the Bond Market's Development and Optimize the Enterprise's Financing Structure}

In the relatively mature capital markets in the world, the development speed and scale of the bond market is far beyond the stock market, while there are many problems in the development of the bond market in China, requiring the constantly improvement of the market system and the expansion of the financing scale. Therefore, the government should provide more favorable conditions for listed companies in policy, such as improving relevant laws and regulations, reducing unnecessary administrative intervention, and encouraging banks to relax the loan restrictions for high-tech enterprises on the Growth Enterprise Market, to promote the development of the bond market. In addition, enterprises should use the capital market financing platform reasonably, appropriately improve the asset-liability ratio, and obtain financial leverage benefits [5].

\subsection{Actively Adjust the Debt Structure to Increase the Use of Long-Term Debt}

Currently, the liability structure of GEM listed companies in China is neither stable nor reasonable. The high proportion of current liabilities will increase the interest rate risk and investment risk of the company and affect the continual operation ability of the company. Therefore, the adjustment of liability structure can be achieved through the debt repayment period and debt source. When choosing financing methods, the actual situation of the enterprise should be considered, and various financing methods should be combined. When the company has had enough total amount of liabilities, it should reasonably allocate the proportion of shortterm liabilities and long-term liabilities, appropriately increase the proportion of long-term liabilities, increase the long-term loan of the bank, and actively issue corporate bonds, to reduce the financial risk and make the company develop steadily. [6] On the other hand, GEM listed companies can improve their financial leverage effect by appropriately repurchasing share. Reducing the number of shares in circulation of GEM listed companies through share repurchase will not affect the company's net assets and shareholders' equity, and it can increase the company's asset-liability ratio, 
return on equity and earnings per share, thus enhancing investors' confidence, and then promoting the rise of stock prices in the secondary market. Increase financial leverage effect

\subsection{Strengthen Internal Management and Improve Internal Financing Capacity}

When making financing choice and determining capital structure, the company should strengthen risk control, improve profitability, accumulate internal funds to provide effective support for the development of the enterprise, by combining various factors such as the enterprise's own characteristics and industry. According to the pecking order theory, internal financing ranks first in the order of corporate financing [7]. If the enterprise wants to improve its internal financing ability, it must improve theits own profitability and development ability, improve the quality of enterprise managers, and form a scientific decision-making mechanism, which are the fundamental problems. Continue to expand the market, make product technology innovation, increase the market share of the product; Appropriately reduce various costs to increase enterprise profits and improve its internal financing ability. In addition, the government should play a dominating role, publishing relevant policies to strengthen the capital support and investment of special funds for GEM listed companies to satisfy the development needs of the enterprise.

\section{CONCLUSIONS}

The comprehensive promotion of optimizing the capital structure of GEM listed companies can be of great help to effectively solve the unbalanced problems of China's capital market development, and further improve the internal management of enterprises and optimize the operation and management of GEM listed companies. With a reasonable capital structure, GEM listed companies can better play the role of financial leverage ratio, thereby achieving the role of tax saving, and improving the ability to resist risks. Thus, to improve the level of financial management, enterprises must put optimizing the enterprises' capital structure in an important place.

\section{REFERENCES}

[1] Anthony, K.C.The impact of capital structure on the performance of microfinance institutions $[\mathrm{J}]$. The Journal of Risk Finance, 2010(1):56-71.

[2] Deangelo H, Deangelo L, Whlted T M.Capital Structure Dynamics and Transitory Debt[J].Journal of Finanial Economics,2011,99(2):235-261.

[3] Fu YAN, Ye LI. Analysis of financing preference of small and medium-sized science and technology enterprises in China - Thinking based on the financial condition of Growth Enterprise Market enterprises [J]. New Finance, 2012 (03): 40-44.

[4] Nan YANG. An analysis of the factors affecting the capital structure of small and medium-sized hightech enterprises on Growth Enterprise Market [J]. Jinan Journal (Philosophy and Social Sciences Edition), 2014, 36 (03): 136-143+164. -58.

[5] Huaiyu TANG. Empirical study on factors affecting the capital structure of Growth Enterprise Market listed companies [J]. China Securities and Futures, 2013, 25 (5): 25- 30.

[6] Guobao XIONG, Ruhui MA. Study on the Influence of Characteristic Factors on Capital Structure of China's Energy Listed Companies [J]. Jiangxi Social Sciences, 2017, 37 (09): 100-108.

[7] Jun WANG. Research on financing structure and Research and Development input of GEM listed companies $[\mathrm{J}]$. Monthly Journal of Accounting, 2019 (04):48

[8] Hua TANG. Empirical analysis on the impact of GEM listed companies' financing preference on corporate performance [J]. Statistics and Decision Making, 2019, 35 (06):182-185. 